\title{
Sediment dynamics in shallow Lake Markermeer, The Netherlands: field/laboratory surveys and first results for a 3-D suspended solids model
}

\author{
P. Kelderman, P. De Rozari, S. Mukhopadhyay and R. O. Ang'weya
}

\begin{abstract}
In 2007/08, a study was undertaken on sediment dynamics in shallow Lake Markermeer, The Netherlands. Firstly, the sediment characteristics median grain size, mud content and loss on ignition showed a spatial as well as water depth related pattern indicating wind-induced sediment transport. Sediment dynamics were investigated in a sediment trap field survey at two stations. Sediment yields, virtually all coming from sediment resuspension, were significantly correlated with wind speeds. Resuspension rates for Lake Markermeer were very high, viz. ca. 1,000 g/m²day as an annual average, leading to high suspended solids (SS) contents, due to the large lake area and its shallowness (high 'Dynamic Ratio'). Sediment resuspension behaviour was further investigated in preliminary laboratory experiments using a 'micro-flume', applying increasing water currents onto five Lake Markermeer sediments. Resuspension showed a clear exponential behaviour. Finally, a 3-D model was set up for water quality and SS contents in Lake Markermeer; first results showed a good agreement between modelled and actual SS contents. Construction of artificial islands and dams will reduce wind fetches and may be expected to cause a substantial decrease in lake water turbidity. Key words | micro-flume, modelling, resuspension, sediment characteristics, sediment traps, suspended solids

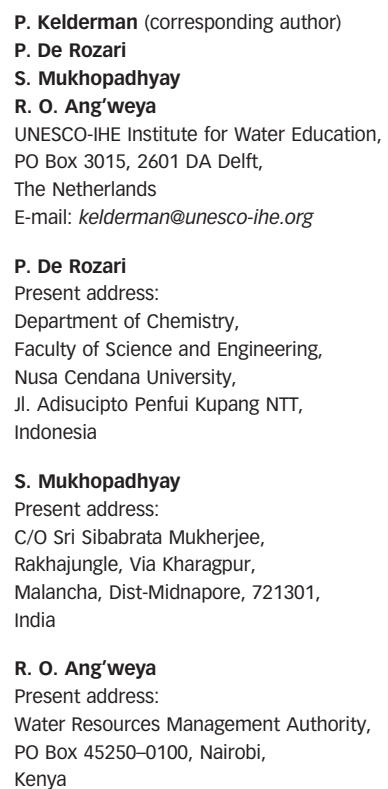

\section{INTRODUCTION}

In shallow lakes, sedimentation and resuspension of bottom materials are mainly driven by wind-induced currents and wave actions. Sediment characteristics, water depth and fetch (i.e. the length of free water surface over which winds can blow) are main determinants for sediment distribution patterns (Håkanson \& Jansson I983; Azza 2006; Vijverberg et al. 20Io). Lake Markermeer is a large $\left(680 \mathrm{~km}^{2}\right)$, shallow (average water depth $3.6 \mathrm{~m})$ freshwater lake $\left(\mathrm{Cl}^{-}<200 \mathrm{mg} /\right.$ L), in the central part of The Netherlands (see Figure 1(a)). It was formed in 1976 by the construction of the 'Houtribdijk', separating it from Lake IJsselmeer. The lake bottom gently slopes towards the East and water depths range from $<0.5 \mathrm{~m}$, mainly on the western shores, to $>5 \mathrm{~m}$, especially in the south east and in a narrow shipping channel near Amsterdam (see Figure 1(b)). About 90\% of the lake is between 2 and $5 \mathrm{~m}$ deep (Van Duin 1992). Water exchange takes place especially with Lake IJsselmeer and the hydraulic residence time in Lake Markermeer amounts to 1-1.5 years
(Van Duin I992; Vijverberg et al. 20I0). Over the last decades, measures have been taken to control point and non-point sources of pollution. Despite this, the water quality of the lake is still sub-optimal with frequent eutrophication events and high turbidities (viz. $45 \mathrm{mg} / \mathrm{L}$ suspended solids as annual average) and low light transparencies; this is probably due to continuous resuspension of bottom material (Van Duin I992; Vijverberg et al. 20I0), driven by the shallowness of the lake and its relatively large open water areas. The present study aimed at getting insight into the processes playing a role in the sediment (re-)distribution in Lake Markermeer; the research has taken place over four months in 2007/08 and comprised the following activities: (a) an inventory of major sediment characteristics at 50 stations; (b) sediment traps field survey at two permanent stations; (c) preliminary laboratory sediment resuspension experiments; (d) set-up and first results of a 3-D lake water quality and suspended solids model. 
(a)

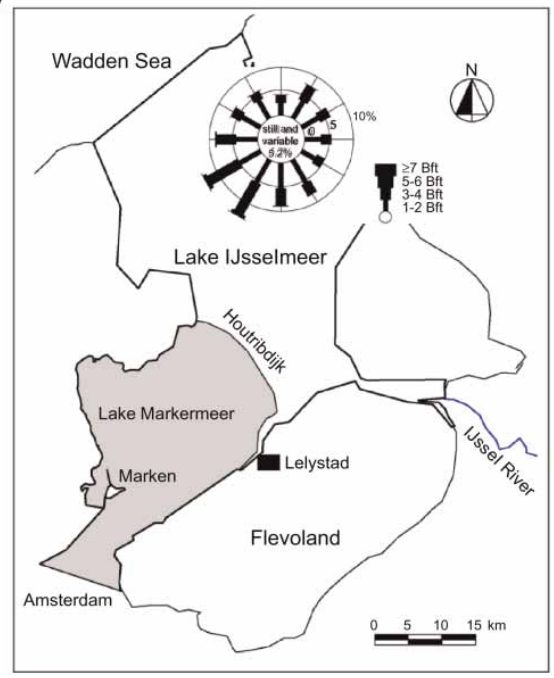

(b)
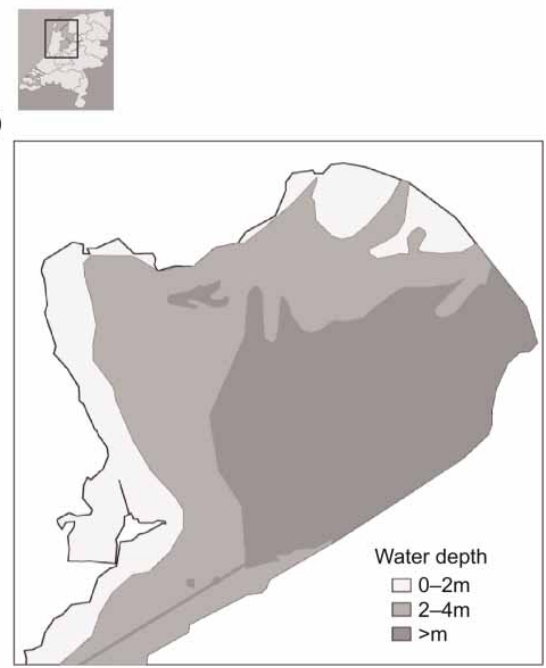

Figure 1 | (a): Lake Markermeer and Lake IJsselmeer (the former 'Zuiderzee' estuary) in central Netherlands. Also indicated is the 'wind rose' for the lake area (average over 1981-2000; KNMI 2010). (b): Water depths distribution in Lake Markermeer (after Van Duin 1992).

\section{MATERIALS AND METHODS}

The following investigations were carried out over the period November 2007-March 2008:

\section{Sediment characteristics}

During cruises in November 2007, sediment grab samples of the upper 2-3 cm were taken with a Van Veen sampler, at 50 stations in Lake Markermeer (see Figure 2(a)) (Ang'weya 2008). The sediment samples were analyzed for, amongst others, median grain size, mud $(<16 \mu \mathrm{m})$ content, and loss on ignition (LOI), as a surrogate for organic matter content (Håkanson \& Jansson 1983). All analyses were according to 'Standard Methods' (APHA/ AWWA/WEF 2005). Also sediment heterogeneity was investigated at four sites (see Figure 2(a); Kelderman et al. 2012).

\section{Sediment trap field survey}

From December 2007 to February 2008, cylindrical sediment traps $(L=50 \mathrm{~cm}$; ID $=4.5 \mathrm{~cm})$, in duplicate, were installed at stations STA and STB (see Figure 2(a)), with water depths 4.2 and $3.2 \mathrm{~m}$, respectively (De Rozari 2008). Traps were installed on the bottom and at half-depth; the stations were visited at 2-weekly intervals. Trapped material was analyzed for sediment yield ( $\mathrm{g}$ dry material $/ \mathrm{m}^{2}$ day) and its composition; for details, see Kelderman et al. (20I2).

\section{Preliminary laboratory sediment resuspension experiments}

Sediment had been collected with a Van Veen grab sampler, at five Lake Markermeer sites; see Figure 2(a). Sediment resuspension experiments were done in a small $(L=6.0 \mathrm{~cm} ; \quad W=14.5 \mathrm{~cm})$ rectangular 'microflume' (Kansiime \& Nalubega 1999), which was filled with a ca. $3 \mathrm{~cm}$ sediment layer, each time with sediment from one of the five Lake Markermeer sites (Kelderman et al. 2012). Tap water was led over the sediment bed; the effluent water was collected with a measuring cylinder. Resuspension behaviour, as monitored through suspended solids (SS) contents of the effluent water, was followed for increasing near-bed currents, ranging from 0 to about $1.5 \mathrm{~cm} / \mathrm{s}$.

\section{Set-up of a Lake Markermeer 3-D model}

An integrated 3-D water quality model for Lake Markermeer was set up, based on Delft 3-D (WL Delft Hydraulics 2007) using $250 \times 250 \mathrm{~m}$ grids. The model works via different modules which integrate hydrodynamics, SS contents and ecological aspects. Water balances were made over the lake for the years 2002-2004; results of these were then used to calculate the nutrient and other in/outputs into/from the lake. The Delft 3-D water quality ('DELWAQ') module was used to model suspended solids in the lake, with wind and wave effects as driving forces. 

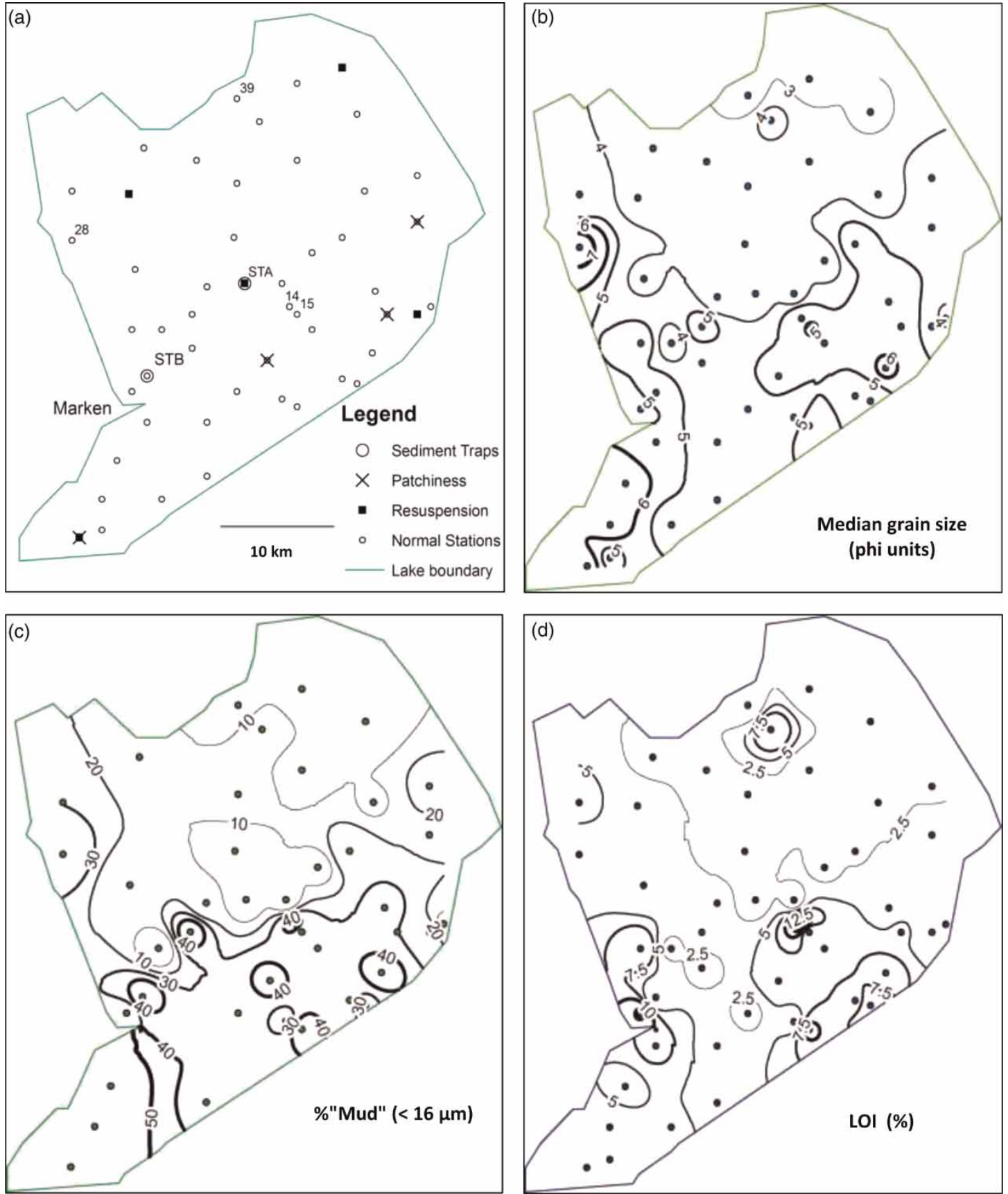

Figure 2 | (a): Locations of the monitoring stations in the Lake Markermeer research: 50 stations for sediment characteristics, and of these: two sediment trap stations STA and STB; four stations for sediment heterogeneity ('patchiness'); five stations for laboratory resuspension experiments. For numbered stations, see text. (b-d): Contour diagrams for the different sediment characteristics at 49 stations (one sample was lost); (b): Median grain size (phi units); (c): Mud content (\%); (d): LOI (\%).

In the model, the lake bed is assumed to consist of two layers, viz. a thin, very 'fluffy' top layer, prone to resuspension under already moderate wind conditions, and a more compact sediment layer hereunder. For each wind/wave condition, two different critical shear stresses, driving sediment resuspension, were then calculated. Calibration and validation of the SS model were done using light extinction data over 2 years, as these quite closely matched with the SS contents in the lake, with calibration carried out over the first half of the years; validation over the second half (Mukhopadhyay 2008). 


\section{RESULTS AND DISCUSSION}

Detailed results have been presented in Kelderman et al. (2012). Overall, the different sediment characteristics in Lake Markermeer showed quite consistent patterns. Median grain size is expressed in phi-units $\left(\varphi=-{ }^{2} \log (d)\right.$, with $d=$ diameter $(\mathrm{mm})$ (e.g. a grain size of $0.25 \mathrm{~mm}=$ $2^{-2} \mathrm{~mm}$ corresponds to 2 phi units)) (Håkanson \& Jansson 1983). $M d_{\varphi}$ values (Figure 2(b)) ranged from 2.5 ('medium sand') at NE station 39 to 7.2 phi units ('medium silt') at NW station 28. Lowest $M d_{\varphi}$ values (coarsest grain sizes) were found in the shallow NE zone near the Houtribdijk, whereas high $M d_{\varphi}$, values, up to $>6.0$ phi units, were generally present in the deeper $(>3-4 \mathrm{~m})$ east zone of the lake. However, overall no significant correlation $(p>0.05 ; t$ test; cf. Ott \& Longnecker 20oI) was found between medium grain size and water depth. This must be due to the overall shallowness of the lake $(\approx 70 \%$ has water depth $<4 \mathrm{~m}$ ), which makes the whole lake susceptible to current and wave actions, causing frequent sediment resuspension and transport. Other factors such as dominant wind direction and fetch may be equally important for sediment grain size distribution (Håkanson \& Jansson 1983; Lick et al. I994; Azza 2006). To investigate effects of local water depth variations, we compared two stations close together (about $500 \mathrm{~m}$ ) (see Figure 2(a)). One station (14) was located in a small, deep pit (water depth $5.5 \mathrm{~m}$ ); the other station (15), with water depth $4.0 \mathrm{~m}$, was just outside the pit. A marked difference was observed here, with fine grained sediment $\left(M d_{\varphi}=6.0\right)$ at station 14 , and intermediate characteristics $\left(M d_{\varphi}=4.9\right)$ at station 15 ; differences were more prominent for the other sediment parameters. Mud content $(<16 \mu \mathrm{m})$ of the Lake Markermeer sediments (Figure 2(c)) was found to be very high, viz. 30-40\% over most of the lake area with extremes up to 57\% in the SW zone. In agreement with the earlier reported $M d_{\varphi}$ results, minimum mud contents were found in the shallow NE zone. These small-sized sediments are highly susceptible to wind and wave driven near-bed currents (Lick et al. I994; Håkanson 2006); this will be the main cause for the high turbidities in Lake Markermeer. Compared with this, the sediment in adjacent Lake IJsselmeer (see Figure 1(a)) consists of ca. 75\% of sand (Vijverberg et al. 2010) and the lake- with similar water depth-shows more than 50\% lower turbidity values (Waterbase 20I0). (Database of water quality data in The Netherlands, from the Ministry of Infrastructure and the Environment).

Loss on Ignition, finally (see Figure 2(d)), ranged from $<0.5 \%$, mainly in the NE part of the lake, to $12.6 \%$ at station 14. High LOI contents will especially be found for finegrained sediments (Håkanson \& Jansson I983); LOI is roughly equivalent to organic carbon (OC) content, with a ratio LOI:OC of ca. 2.

\section{Sediment trap field survey}

Sediment yields at STA and STB showed on average 8.4\% differences between duplicate traps. The patterns of sediment yields at the two stations were markedly similar (see Figure 3; De Rozari 2008), with average bottom trap yields at STA of $1,194 \mathrm{~g} / \mathrm{m}^{2}$ day and $2,557 \mathrm{~g} / \mathrm{m}^{2}$ day at STB. The higher yield at STB must be due to: (1) its lower water depth (3.2 vs. $4.2 \mathrm{~m}$ ), making it more prone to wind-induced sediment resuspension; and (2) its finer sediment type, with higher values for $M d_{\varphi}$ and mud content (Figure 2(b), (d)). Sediment yields for the half-depth traps were some $45 \%$ lower than the bottom trap yields. Assuming that the sediment trap material consists virtually only of resuspended sediment, we may expect an exponential relationship between average wind speed $W(\mathrm{~m} / \mathrm{s}$ ) at Lelystad (cf. Figure 1(a); KNMI 20Io) and sediment yield $Y$ (g/m day). Indeed, stations STA and STB showed exponential relationships $\left(R^{2}=0.68-0.69 ; p<0.05\right.$ for $n=7$ observations), viz. for STA: $Y=32.4 \times W^{2.1}$; for STB: $Y=14.8 \times W^{2.3}$. However, also periods of strong winds were shown to have a large impact on the sediment yields (Kelderman et al.

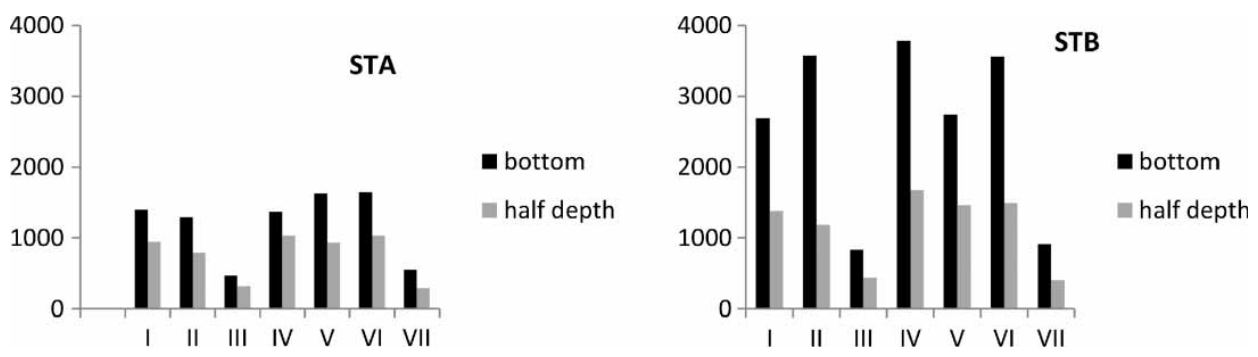

Figure 3 Sediment trap yields ( $\mathrm{g} / \mathrm{m}^{2}$ day) at stations STA and STB (see Figure1 (a)) bottom and half-depth traps, for seven 2-week periods from 4 December 2007 to 26 March 2008 (for details, see Kelderman et al. 2012). 
20I2). The LOI, total $N$ and $P$ contents closely matched those of the material at the deep pit station 14 (see Figure 2); this indicates that indeed the trapped material consists virtually all of resuspended sediment materials (Bloesch 1995; Weyhenmeyer et al. 1995).

Due to budget and time restrictions, we could only carry out the sediment trap survey over a period of 3 months. Large seasonal differences may be expected for sediment yields, especially due to wind speed variations. Taking into account the annually averaged wind speed, and applying the above two formulae, we could derive a sediment yield of, on average, $995 \mathrm{~g} / \mathrm{m}^{2}$ day for Lake Markermeer. This value is very high but comparable with other large, shallow lakes such as Lake IJsselmeer and Lake Balaton (Håkanson 2006); for these lakes with DM values (DM = Dynamic ratio $=\left[\left(\text { lake area, in } \mathrm{km}^{2}\right)^{1 / 2}\right] /$ average water depth, $\left.\mathrm{m}\right)>7$, virtually the whole lake area will be under the influence of sediment resuspension. The above was supported by the fact that only in a few deep areas accumulation of muddy material had taken place, as was shown by Echo sounding field surveys (Vijverberg et al. 20Io). Also, using ${ }^{137} \mathrm{Cs}$ sediment dating, 5-10 times higher ${ }^{137} \mathrm{Cs}$ contents were found for sediment inside 'deep pit' station 14, than just outside it (15).

\section{Preliminary laboratory micro-flume experiments}

Using a small micro-flume set-up, we estimated SS concentrations as a function of near-bed currents for five Lake Markermeer sediments (see Figure 2(a)). Starting from zero and slowly increasing the bottom current, sediment resuspension started off at $0.5-0.7 \mathrm{~cm} / \mathrm{s}$. For higher nearbed currents, an exponential increase could then be observed with values up to 500-3,500 $\mathrm{mg}$ SS/L for a velocity of $1.3 \mathrm{~cm} / \mathrm{s}$ (Kelderman et al. 20I2); see Figure 4. Taking averages over the five stations, we estimated the following exponential relationship between SS content $(\mathrm{mg} / \mathrm{L})$ and near-bed velocity $C(\mathrm{~cm} / \mathrm{s})$ :

$\mathrm{SS}=27 \times \mathrm{e}^{3.4 C}\left(R^{2}=0.96\right)$

Making use of field data of near-bed currents in Lake Markermeer (Vijverberg et al. 20IO), and correcting for average annual wind speeds (KNMI 20IO), we arrived at an average near-bed current $C=1.5 \mathrm{~cm} / \mathrm{s}$ in Lake Markermeer. This would result in an average SS content of $4,430 \mathrm{mg} / \mathrm{L}$ in the micro-flume and, accordingly, of ca. $100 \mathrm{mg} / \mathrm{L}$ for Lake Markermeer (average water depth $=3.6 \mathrm{~m}$ vs. $8 \mathrm{~cm}$

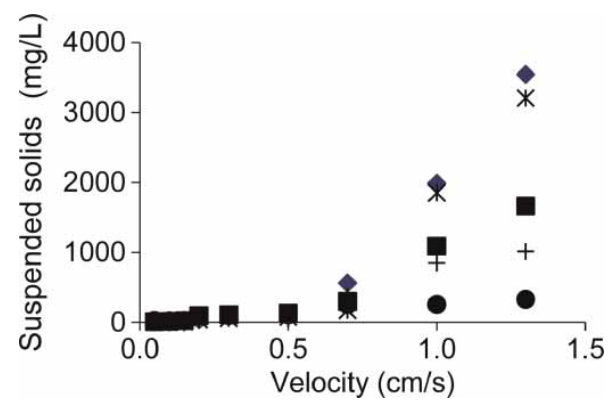

Figure 4 | Suspended solids contents (mg/L) in the effluent as a function of near-bed velocity, in the laboratory 'micro-flume' for five sediment stations (see Figure 2 (a)) of Lake Markermeer.

in the micro-flume). This is substantially higher than the actual suspended solids contents in the lake, viz. $45 \pm$ $18 \mathrm{mg}$ SS/L (Waterbase 20I0). However, vertical SS gradients, with two to three times higher SS contents near the sediment bed, were often observed in Lake Markermeer (Vijverberg et al. 20Io).

It can be concluded that, despite its limitations (e.g. disturbed sediment samples, destruction of the 'fluffy' top layer; possible sediment compaction; 'biofilms' by benthic organisms (Bailey \& Hamilton 1997; Kleeberg et al. 2008; Egemose et al. 2009)), these simple micro-flume experiments can form a basis for the follow-up experiments that currently take place, and which involve intact, undisturbed sediment cores (De Lucas Pardo, in preparation).

\section{Lake Markermeer modelling}

Good results were achieved in modelling suspended solids contents in Lake Markermeer, station 14 (see Figure 5;

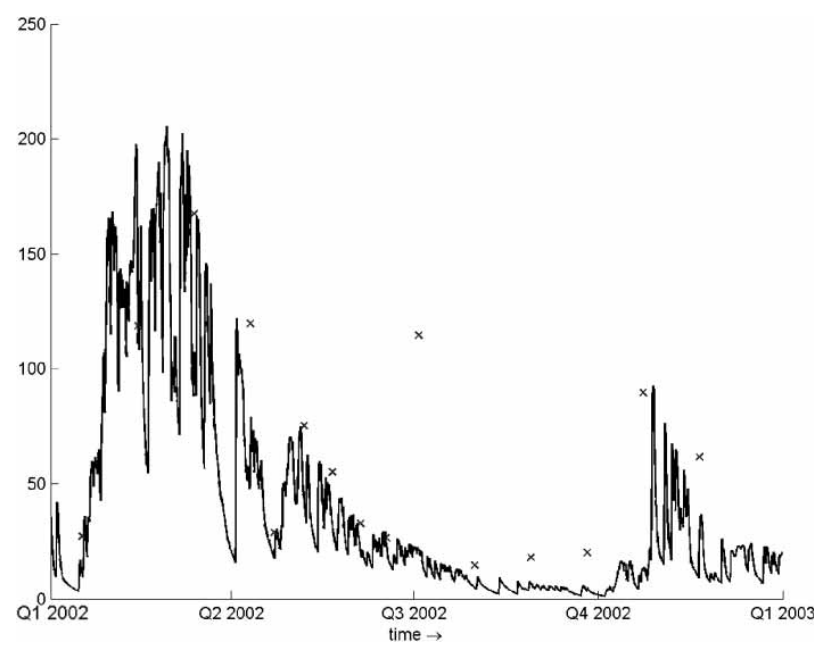

Figure 5 | Modelled (-) and actual (x) suspended solids contents (mg/L) over 2002/03 in Lake Markermeer, station 14 (see Figure 2(a)). 
Mukhopadhyay 2008). The discrepancies between modelled and actual SS contents in the third quarter of 2002 may be due to an underestimation of the sediment settling rate (Mukhopadhyay 2008). Next we modelled the behaviour of two different sediment fractions in Lake Markermeer, viz. the 'fluffy' extreme sediment top layer and the more coarse sediment type hereunder. The model outcome (see Figure 6; Mukhopadhyay 2008) clearly shows the high turbidity caused by especially the 'fluffy' sediment, in the NE zone of the lake; here the impact of the dominant W-SW winds is largest (highest fetch).

We also tried out the possible effect of one of the scenarios to reduce the high SS contents in Lake Markermeer, viz. construction of a thin dam as an artificial wind barrier, separating Lake IJmeer from Lake Markermeer (see Figure 6). This scenario is in line with the government's plan to construct small wind barriers to minimize the wind effects on Lake Markermeer. Due to the prevailing SW wind direction (see Figure 1(a)), a reduction in SS may be expected, not only in Lake IJmeer, but also in parts of Lake Markermeer proper.

Indeed, a reduction $>50 \%$ in SS contents was found for Lake IJmeer in the case of the wind barrier; however, the SS contents in Lake Markermeer did not change much (Mukhopadhyay 2008). A possible reason for the latter could be the still remaining high fetch values in the SW direction, for which the effect of the dam is relatively small. In the model, the height of the dam was taken as $1.0 \mathrm{~m}$, which is possibly insufficient to substantially reduce the effect of high wind speeds (Mukhopadhyay 2008).

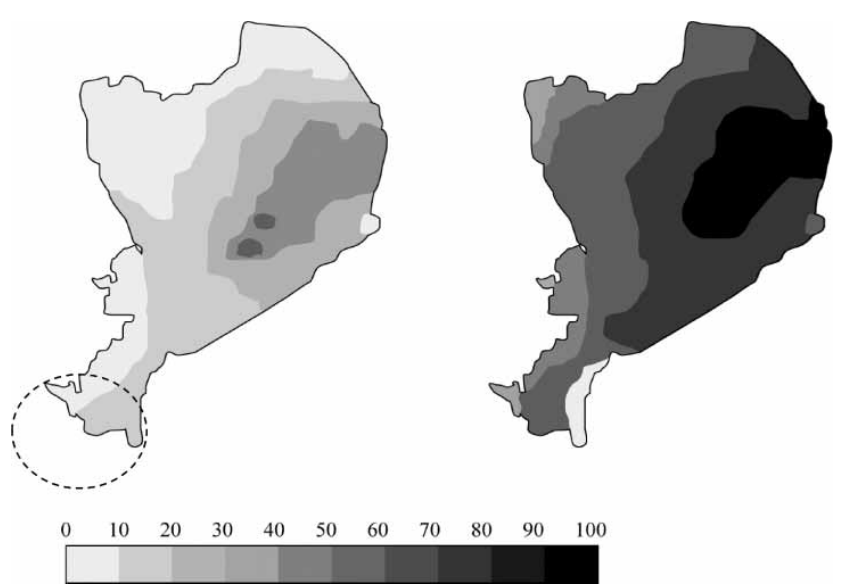

Figure 6 | Modelled SS content (mg/L) for the 'coarse' (left) and 'fluffy' (right) sediment fraction in Lake Markermeer, as model outcome for the lake conditions on 2 March 2002. The encircled area indicates Lake IJmeer near Amsterdam, see text. Figure redrawn from Mukhopadhyay (2008).
For the abatement of the high turbidities in Lake Markermeer, another feasible option to reduce the effective wind fetches in the lake would be the creation of artificial wetlands near the centre of the lake. In that case wave heights and, consequently, near-bed currents would be much reduced (http://www.delftcluster.nl/website/nl/page831.asp.; website in Dutch; accessed 30 September 2010). Thus, reducing the average fetch by a factor of 2 (from the present ca. $15 \mathrm{~km}$ to ca. $8 \mathrm{~km}$ ) would reduce near-bed currents in Lake Markermeer by 30-50\% (Håkanson \& Jansson I983; Lick et al. I994), i.e. from the present average $1.5 \mathrm{~cm} / \mathrm{s}$ to $0.9 \mathrm{~cm} / \mathrm{s}$. Using above Equation (1) from the laboratory resuspension experiments, this would lead to $>80 \%$ reduction in the SS contents in Lake Markermeer. Another possible measure for SS reduction would be the construction of large deep pits in the lake, serving as 'final sedimentation basins' for resuspended sediment materials. This option is currently being studied, amongst others, by using the just discussed 3-D model for sediment dynamics in Lake Markermeer (Vijverberg et al. 20Io).

\section{CONCLUSIONS}

This study has shown the large impact of the dominant SW winds on the muddy sediment bed of Lake Markermeer. The lake, with its large surface area and shallow depth, is very susceptible to wind-induced sediment resuspension and transport. A substantial reduction in lake water turbidities can only be brought about by reducing effective wind fetches, thus reducing near-bed currents. Field investigations measuring in-situ sediment dynamics, as well as laboratory experiments on 'undisturbed' sediment cores, can bring further insight here. Factors of importance are e.g. wave dynamics, near bottom currents and critical shear stresses for sediment entrainment. Modelling efforts could best be concentrated on the effect of small wetlands at different locations in the lake, as effective 'wind barriers' which will reduce wind fetches, and therefore SS contents, in the lake.

\section{REFERENCES}

Ang'weya, R. O. 2008 Sediment characteristics of Lake Markermeer, The Netherlands. UNESCO-IHE MSc Thesis ES 08.34, Delft, The Netherlands.

APHA/AWWA/WEF 2005 Standard Methods for the Examination of Water and Wastewater (2005), 21st edition. Washington DC, USA. 
Azza, N. G. T. 2006 The dynamics of shoreline wetlands and sediments of northern Lake Victoria. UNESCO-IHE PhD Thesis, Taylor \&Francis/Balkema, Leiden, The Netherlands.

Bailey, M. C. \& Hamilton, D. P. 1997 Wind induced sediment resuspension: a lake-wide model. Ecological Modelling 99, 217-228.

Bloesch, J. 1995 Mechanisms, measurements and importance of sediment resuspension in lakes. Marine and Freshwater Resources 46, 295-304.

De Rozari, P. 2008 Sediment dynamics in Lake Markermeer, The Netherlands. UNESCO-IHE MSc Thesis WM 08.02, Delft, The Netherlands.

Egemose, S., Wauer, G. \& Kleeberg, A. 2009 Resuspension behaviour of aluminium treated lake sediments: effects of aging and pH. Hydrobiologia 636, 203-217.

Håkanson, L. 2006 Suspended Particulate Matter in Lakes, Rivers, and Marine Systems. Blackburn Press, Caldwell, USA.

Håkanson, L. \& Jansson, M. I983 Principles of Lake Sedimentology. Springer Verlag, Berlin, Germany.

Kansiime, F. \& Nalubega, M. I999 Wastewater treatment by a natural wetland: the Nakivubo swamp, Uganda-processes and implications. PhD Thesis. IHE/WUR, Balkema, Rotterdam, The Netherlands.

Kelderman, P., Ang'weya, R. O., De Rozari, P. \& Vijverberg, T. 2012 Sediment characteristics and wind-induced sediment dynamics in shallow Lake Markermeer, The Netherlands. Aquatic Sciences 74 (2), 301-313.

Kleeberg, A., Hupfer, M. \& Gust, G. 2008 Quantification of phosphorus entrainment in a lowland river by in situ and laboratory resuspension experiments. Aquatic Sciences 70, 87-99.
KNMI 20Io Available from: http://www.knmi.nl/klimatologie/ daggegevens/index.cgi (website in Dutch; accessed 15 September 2010).

Lick, W., Lick, J. \& Ziegler, C. K. 1994 The resuspension and transport of fine-grained sediments in Lake Erie. Journal of Great Lakes Research 20 (4), 599-612.

Mukhopadhyay, S. 2008 Setup of a water quality model of the Markermeer: a turbid shallow lake. UNESCO-IHE MSc Thesis ES 08.23, Delft, The Netherlands.

Ott, R. L. \& Longnecker, M. 200I An Introduction to Statistical Methods and Data Analysis. 5th edition. Wadsworth Group, Duxbury, USA.

Van Duin, E. H. S. 1992 Sediment transport, light and algal growth in the Markermeer - a two dimensional water quality model for a shallow lake. $\mathrm{PhD}$ thesis, Wageningen Agricultural University, Wageningen.

Vijverberg, T., Winterwerp, J. C., Aarninkhof, S. G. J. \& Drost, H. 20Io Fine sediment dynamics in a shallow lake and implication for design of hydraulic works. Ocean Dynamics 61 (2-3), 187-202.

Waterbase 20Iо Available from: http://live.waterbase.nl (accessed 20 October 2010).

Weyhenmeyer, G. A., Meili, M. \& Pierson, D. C. 1995 A simple method to quantify sources of settling particles in lakes: resuspension versus new sedimentation from planktonic production. Marine and Freshwater Resources 46, 223-231.

WL|Delft Hydraulics 2007 Delft-3D Flow Manual Simulation of multi-dimensional hydrodynamic flows and transport phenomena, including sediments. Internal Report, Delft, The Netherlands. 
Copyright of Water Science \& Technology is the property of IWA Publishing and its content may not be copied or emailed to multiple sites or posted to a listserv without the copyright holder's express written permission. However, users may print, download, or email articles for individual use. 